\title{
Dental Characteristics of Late Pleistocene Equus Lambei from the Bluefish Caves, Yukon Territory, and their Comparison with Eurasian Horses \\ La dentition de Equus lambei du Pléistocène supérieur provenant des grottes du Poisson Bleu (Yukon) et sa comparaison avec celle des chevaux eurasiens Zahncharakteristika von Equus lambei im späten Pleistozän von den Bluefish-Grotten, Yukon-Gebiet, und ihr Vergleich mit eurasischen Pferden
}

Ariane Burke et Jacques Cinq-Mars

Volume 50, numéro 1, 1996

URI : https://id.erudit.org/iderudit/033077ar

DOI : https://doi.org/10.7202/033077ar

Aller au sommaire du numéro

Éditeur(s)

Les Presses de l'Université de Montréal

ISSN

0705-7199 (imprimé)

1492-143X (numérique)

Découvrir la revue

Citer cet article

Burke, A. \& Cinq-Mars, J. (1996). Dental Characteristics of Late Pleistocene Equus Lambei from the Bluefish Caves, Yukon Territory, and their Comparison with Eurasian Horses. Géographie physique et Quaternaire, 50(1), 81-93.

https://doi.org/10.7202/033077ar

\section{Résumé de l'article}

Les grottes du Poisson Bleu présentent les témoins les plus anciens découverts in situ d'une occupation humaine en Béringie orientale, associés à la faune la plus nombreuse et diversifiée trouvée dans la région. On présente ici les données issues de l'étude d'un important échantillon de dents de cheval récupérées dans les trois grottes. Cette recherche contribue à enrichir nos connaissances sur Equus lambei. La comparaison de la dentition de Equus lambei avec celle des chevaux contemporains d'Europe montre que leur dents sont de taille similaire. À la faveur de cette comparaison l'hypothèse d'une réduction de la taille des équidés survenue au Pleistocene supérieur est envisagée. 


\section{DENTAL CHARACTERISTICS OF LATE PLEISTOCENE EQUUS LAMBEI FROM THE BLUEFISH CAVES, YUKON TERRITORY, AND THEIR COMPARISON WITH EURASIAN HORSES}

Ariane BURKE* and Jacques CINQ-MARS, respectively Department of Anthropology, University of Manitoba, 435 Flertcher Argue Boulevard, Winnipeg, Manitoba R3T 5V5, and Archaeological Survey of Canada, Canadian Museum of Civilization 100, rue Laurier, Hull, Québec J8X 4H2.

ABSTRACT Dental characteristics of Late Pleistocene Equus lambei from the Bluefish Caves, Yukon Territory, and their comparison with Eurasian horses. Bluefish Caves I, II and III of northern Yukon, have yielded the earliest in situ evidence of human occupation of Eastern Beringia, associated with one of the largest and most diverse Late Pleistocene faunas recovered in the region. This paper presents data derived from the study of a large sample of horse teeth recovered from the three caves. This research contributes to our knowledge of the Late Pleistocene Beringian equid, Equus lambei. A comparison of the dentition of $E$. lambei with that of some contemporary European horses, indicates they have similar size cheekteeth. The hypothesis of a Late Pleistocene trend of size reduction in equids is considered in the light of this comparison.
RÉSUMÉ La dentition de Equus lambei du Pléistocène supérieur provenant des grottes du Poisson Bleu (Yukon) et sa comparaison avec celle des chevaux eurasiens. Les grottes du Poisson Bleu présentent les témoins les plus anciens découverts in situ d'une occupation humaine en Béringie orientale, associés à la faune la plus nombreuse et diversifiée trouvée dans la région. On présente ici les données issues de l'étude d'un important échantillon de dents de cheval récupérées dans les trois grottes. Cette recherche contribue à enrichir nos connaissances sur Equus lambei. La comparaison de la dentition de Equus lambei avec celle des chevaux contemporains d'Europe montre que leur dents sont de taille similaire. À la faveur de cette comparaison l'hypothèse d'une réduction de la taille des équidés survenue au Pléistocène supérieur est envisagée.
ZUSAMMENFASSUNG Zahncharakteristika von Equus lambei im späten Pleistozän von den Bluefish-Grotten, Yukon-Gebiet, und ihr Vergleich mit eurasischen Pferden. Die Bluefish-Grotten I, II und III von Nord-Yukon haben den frühesten Beleg in situ über menschliche Besiedlung von Ost-Bering erbracht, in Verbindung mit einer der bedeutendsten und abwechslungsreichsten Fauna des späten Pleistozäns, die man in diesem Gebiet finden konnte. Dieser Aufsatz stellt Daten vor, die bei der Studie einer bedeutenden Sammlung von Pferdezähnen aus den drei Grotten gewonnen wurden. Diese Forschungsarbeit bereichert unsere Kenntnisse über Equus lambei im späten Pleistozän. Ein Vergleich der Dentition von E. lambei mit der einiger zeitgenössischer europäischer Pferde zeigt, daß ihre Backenzähne fast gleicher Größe sind. Die Hypothese, daß im späten Pleistozän ein Trend zum Kleinerwerden der Pferde bestand, wird im Licht dieses Vergleichs in Erwägung gezogen. 


\section{INTRODUCTION}

The paleoenvironmental record for eastern Beringia is preserved virtually intact in many deposits in the northern Yukon, Northwest Territories and Alaska. These deposits yield an almost continuous record of environmental conditions during the last glacial period, or Wisconsinan (Hughes et al., 1981; Harington, 1978; Morlan, 1980). They have been the focus of several multi-disciplinary projects, such as the Northern Yukon Research Programme (Irving et al., 1989), the Yukon Refugium Project (Hughes et al., 1981) and an ongoing, long-term study of Pleistocene vertebrate fossils undertaken by the Canadian Museum of Nature (Harington, 1989).

Unglaciated lowland areas in eastern Beringia, including the Bonnet Plume, Old Crow, Bluefish and Bell basins, may have played a part in the peopling of the New World, particularily during the maximum expansion of the Cordilleran and Laurentide ice sheets. For this reason archaeologists seek a better understanding of Late Pleistocene environments in this region.

The floral and faunal communities of eastern Beringia, though still poorly known, appear to have differed fundamentally from present tundra communities (Harington, 1977; Guthrie, 1982, 1985a; Matthews, 1982; inter alii). The Mammoth Fauna, a widespread faunal community during the Late Pleistocene in Beringia, was dominated by mammoth, horse and bison (Guthrie, 1982, 1985a; Matthews, 1982; Vereshchagin and Baryshnikov, 1982), and only loosely associated with elements such as Saiga and Ovibos. At Bluefish Caves (Fig. 1), however, elements of the Mammoth Fauna are closely associated with both Saiga and Ovibos. A better un-

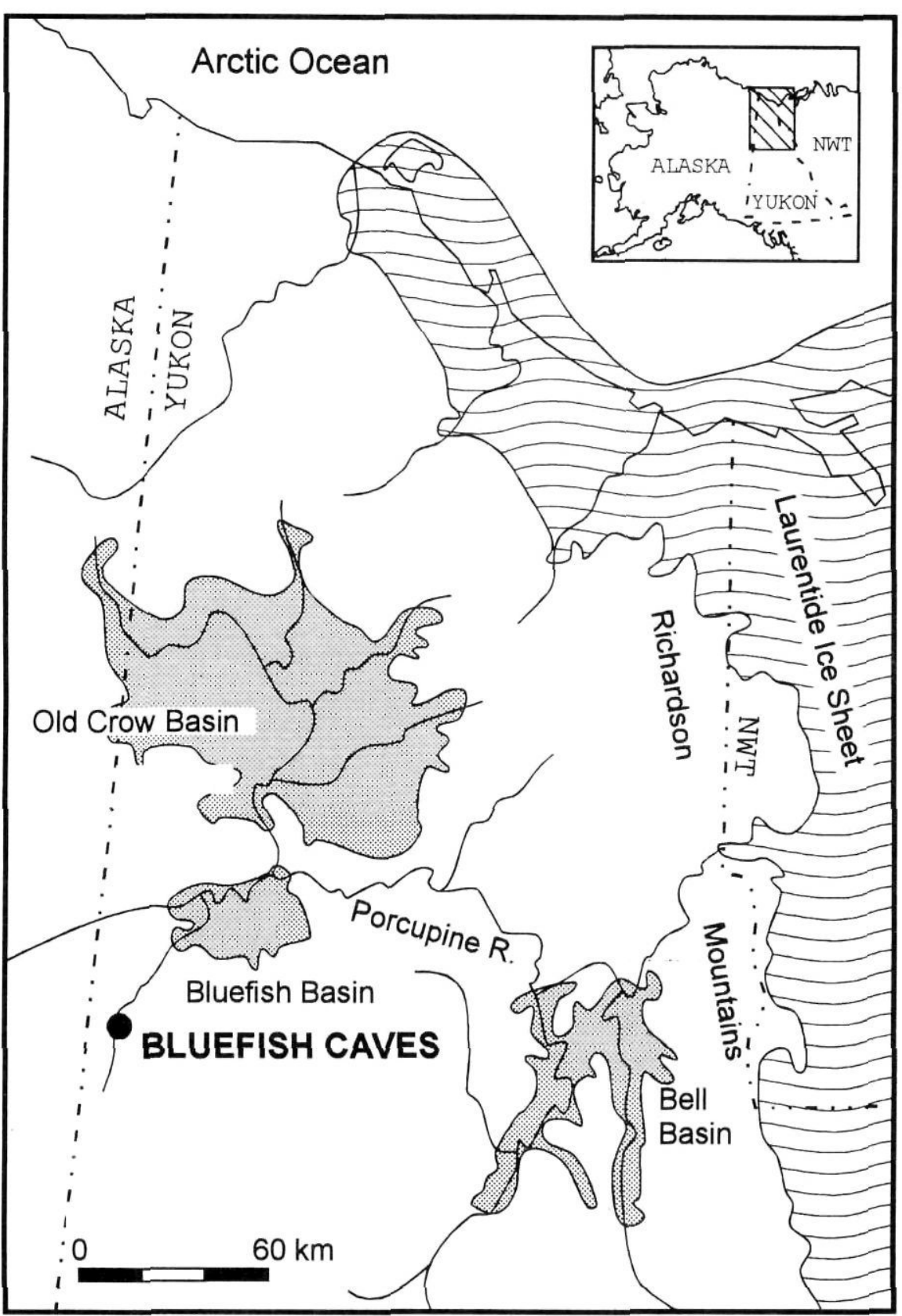

Géographie physique et Quaternaire, 50(1), 1996
FIGURE 1. Map showing the location of the Bluefish Caves relative to the distribution of the northern Yukon-eastern Beringian, Late Pleistocene glacial lake basins and the northernmost boundaries of the Late Wisconsinan Laurentide Ice Sheet.

Carte de localisation des grottes du Poisson Bleu (nord du Yukon) en relation avec la répartition des lacs glaciaires au Pléistocène supérieur et des marges septentrionales de I'Inlandsis laurentidien du Wisconsien supérieur. 
derstanding of Late Pleistocene faunal communities in eastern Beringia has been hampered by the lack of in situ, identifiable biocenoses (Matthews, 1982; Guthrie, 1985a).

The presence of in situ palynological remains, and abundant faunal remains in the three Bluefish Caves, make this an invaluable assemblage for furthering our knowledge of animal communities and their environment in eastern Beringia.

\section{HORSE REMAINS FROM THE BLUEFISH CAVES}

Horse remains have been discovered at Bluefish Caves in stratigraphic contexts spanning the last 15,000 years of the Late Pleistocene (Cinq-Mars, 1990). These fossils help clarify the relationship between the behaviour and morphology of Beringian equids, and paleoenvironmental conditions during the Late Pleistocene.

At Bluefish Caves, teeth are numerous and well-preserved. Furthermore, teeth, and third metacarpals, have proven useful as a basis for taxonomic determinations of Pleistocene fossil horses (Prat, 1976, 1980; Eisenmann, 1980, 1986, 1991; Azzaroli, 1990). Dental measurements have also been used as a measure of overall body size in Pleistocene equids (supra, and see MacFadden, 1992: 269). Here, we describe the dentition of Equus lambei for purposes of taxonomic comparison with the Pleistocene equids of Europe. Postcranial remains of Equus lambei from Bluefish Caves are currently under study (C.R. Harington, Canadian Museum of Nature).

The possibility of detecting trends in the body-size of Eurasian Late Pleistocene equids is controversial (Forstén, 1991; Eisenmann, 1991). The correlation between trends in equid body-size and Pleistocene climatic phases is not well established (Forstén, 1993), although its potential evolutionary significance has been recognized (Forstén, 1991, 1993; Eisenmann, 1991). We help to clarify relationships between equid body size and climate by giving the tooth measurements of a local population, or deme, of horses, from a well-defined Late Pleistocene environment.

\section{DATING OF E. lambei REMAINS IN EASTERN BERINGIA}

Equus lambei, the horse represented in the Bluefish fauna, is characteristic of Wisconsinan faunas in the steppe-like terrain of eastern Beringia (Harington and Clulow, 1973; Harington, 1978:84, 1980). E. lambei appears in pre-Late Wisconsinan deposits in Dawson, Old Crow and Alaska, and in Illinoian age deposits in Alaska (Hughes et al., 1981). At Bluefish, Equus lambei specimens have been radiocarbon dated between: 12,900 \pm 100 BP (GSC 28881, E. lambei femur, cave I) and 17,440 $\pm 220 \mathrm{BP}$ (RIDDL 278, E. lambei metatarsal, cave I). Two additional bone fragments, identified as equid, have been dated to $12,290 \pm 440$ (NMC 1236, cave III) and 22,680 \pm 530 (NMC 1237, cave II) respectively.

A relatively small, broad-skulled horse, Equus lambei strongly resembles Late Pleistocene equids from Siberia (Harington, 1974: 647; Eisenmann, 1986: 72). The type specimen, from Gold Run Creek, Alaska, was first described by Hay in 1917.
Equus lambei has been variously described as a member of the genus Asinus (Groves and Mazak, 1967; Harington, 1977), as a caballine (Savage, 1951, as quoted in Harington, 1977: 630; Groves 1974) and as an onager (Quinn 1957, as quoted in Harington 1977: 630). E. lambei is now firmly assigned to the caballine group on the basis of physical traits described by Harington (1980) and Forstén (1986), and multivariate analyses carried out by (Eisenmann, 1980, 1986). Eisenmann noted close similarities between Equus lambei, Late Pleistocene European and Siberian horses, and modern ponies. Similarily, Forstén (1988a:163) states that E. lambei, the Yukon horse, was "the easternmost

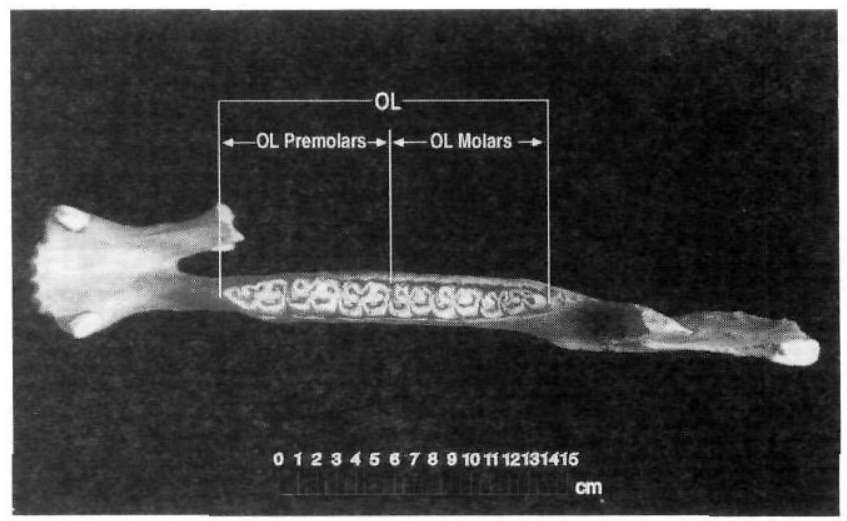

FIGURE 2. E. lambei mandible, Bluefish Caves (Cave III). OL stands for occlusal length, measured including the band of coronal cementum (OLe is measured on the enamel only).

Mandibule de E. lambei, grottes du Poisson Bleu (grotte III). OL indique la longueur occlusale incluant le cément (OLe est mesuré à partir de l'émail).

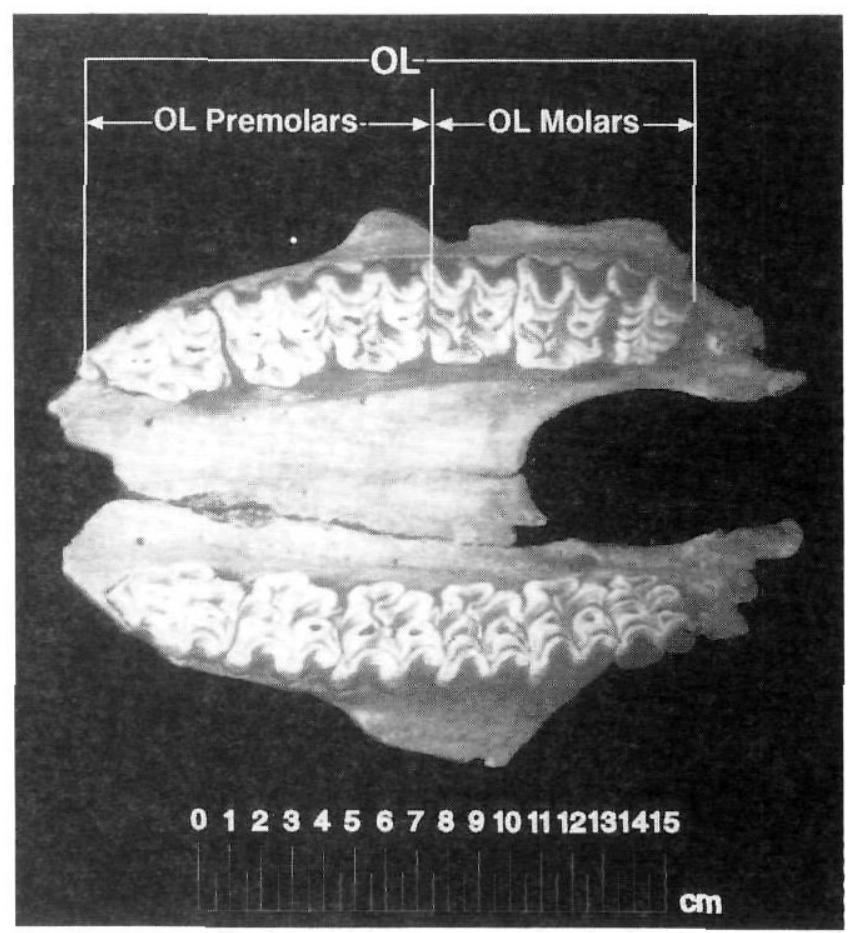

FIGURE 3. E. lambei maxilla, Bluefish Caves (Cave III). Maxillaire de E. lambei, grottes du Poisson Bleu (grotte III). 
representative of a circumpolar species of small, caballoid, horse of which Przelwalski's horse and the tarpan were the last wild Eurasian survivors". The inclusion of E. lambei into the caballoid group is now accepted by Harington (1989: 95).

\section{METHODOLOGY}

The Bluefish Caves have yielded 524 horse cheekteeth, so far: 306 upper, and 218 lower. (Figs. 2 and 3). The teeth

\section{TABLE I}

Qualitative data for E. lambei, following Eisenmann (1986) (upper cheekteeth/complete rows only)

\begin{tabular}{lcccc}
\hline & $\begin{array}{c}\text { P3/P4 } \\
\text { char.1 }\end{array}$ & $\begin{array}{c}\text { M3 } \\
\text { char.2 }\end{array}$ & $\begin{array}{c}\text { M3 } \\
\text { char.3 }\end{array}$ & $\begin{array}{c}\text { P1 } \\
\text { char.4 }\end{array}$ \\
\hline T.P.1-F-35 g & 5 & 0 & 1 & $?$ \\
T.P.1-F-35 d & 6 & 0 & 0 & $?$ \\
M-9-94 d & 6 & 0 & 1 & $?$ \\
M-9-94 g & 7 & 0 & 0 & 0 \\
$85-115 \mathrm{~d}$ & 5 & 1 & 0 & 0 \\
$85-115 \mathrm{~g}$ & 6 & 0 & 0 & $?$ \\
$85-62 \mathrm{~d}$ & 7 & $?$ & $?$ & 1 \\
$85-62 \mathrm{~g}$ & $7(\mathrm{dP} 4)$ & $?$ & $?$ & 1 \\
S-3-79 d & 8 & 0 & 1 & 0 \\
T.P.1-E-46 d & 5 & 0 & 1 & 1 \\
T.P.1-E-46 g & 6 & 0 & 1 & 0 \\
M-9-111+112d & 7 & 0 & 0 & 0 \\
M-9-111+112g & 6 & 0 & 0 & 0 \\
T.P.1-E-61 & 5 & 0 & 0 & $?$ \\
$85-120$ & 5 & 1 & 0 & $?$ \\
E3-4-3 & 7 & 0 & 0 & $?$ \\
$85-M I S C-2.1$ & $5-6$ & 0 & 0 & 0 \\
G7(E1/2)-9-1 & 4 & 0 & 1 & $?$ \\
TOTALS (N=18) & $6 \%$ & $11 \%$ & $33.3 \%$ & $?$ \\
\hline
\end{tabular}

Char.1 - \# folds on P3/P4. Char.2 - isolated hypoglyphs on M3. Char. 3 - open post-fossettes on M3.Char. 4 - presence dP1 on adult specimen.

Adjusted totals: with the addition of isolated M3s :

\begin{tabular}{lcccc}
\hline & Char.1 & Char.2 & Char.3 & Char.4 \\
\hline Bluefish Average & 6 & $10.3 \%$ & $34.5 \%$ & $16.0 \%$ \\
Values & $(\mathrm{N}=18)$ & $(\mathrm{N}=29)$ & $(\mathrm{N}=29)$ & $(\mathrm{N}=18)$ \\
\hline
\end{tabular}

Isolated M3s :

\begin{tabular}{lcc}
\hline M3 & char.2 & char.3 \\
\hline H7(E)-20-5 & 0 & 0 \\
H7(E0-16-9 & 0 & 0 \\
G7(E1/2)-11-11 & 0 & 0 \\
J8-1-138 & 1 & 1 \\
K7-5-20 & 1 & 1 \\
I7-1-56 & 0 & 1 \\
E6-4-55 & 0 & 0 \\
S-3-9 & 0 & 0 \\
$85-M I S C-34$ & 0 & 0 \\
$85-M I S C-132$ & 0 & 1 \\
$85-41$ & 0 & 0 \\
TOTALS $(\mathrm{N}=11)$ & $36.4 \%$ & $9 \%$ \\
\hline
\end{tabular}

were sorted by anatomical position where possible, and the total number of teeth for each position was calculated. The dental MNI (Minimum Number of Individuals) based on cheek teeth is 51 (25 individuals from Cave I, 13 from Cave II and 13 from Cave III).

Mandibular cheekteeth were measured on seven dimensions, maxillary teeth on five dimensions. Measurements were taken following Turnbull (1986), at the occlusal surface for ease of comparison with Eisenmann's (1980) morphometric data. Prat (1968) suggests measuring $2 \mathrm{~cm}$ from the base, or fork, of the roots, in an attempt to control for the reduction in total occlusal surface area which occurs with age. Eisenmann (1980: 81), however, notes that this technique does not improve accuracy since teeth at similar heights are sometimes not at the same wear stage; furthermore, it makes some measurements (e.g. protocone length) more difficult. Measuring near the tooth root also necessitates the removal of teeth from the jaw in cases where tooth rows are intact. A series of qualitative observations were also made on the upper cheekteeth following Eisenmann (1986: fig. 19).

The quantitative data are used to confirm the taxonomic affiliation of $E$. lambei, to describe the dental characteristics of $E$. lambei more fully than before, and to compare $E$. lambei with various Eurasian horses measured by Eisenmann (1980, 1986). Upper cheekteeth are preferred over lower cheekteeth or incisors in these comparisons, as they are the tooth category which has received the fullest treatment in the literature (e.g., Levine, 1982; Turnbull, 1986; Zeder, 1986; Eisenmann, 1990; Forstén, 1990, 1991). Finally, incisors are notoriously difficult to identify as to anatomical position once they are loose, and are frequently under-represented in archaeological assemblages.

\section{RESULTS}

Qualitative dental characteristics of $E$. lambei (Table I) are only roughly similar to those of $E$. przewalskii, the only living representative of the wild horse (for full description of these characteristics, see Eisenmann, 1986: fig.19). The average number of enamel folds on P3 and P4 is higher in our sample of $E$. lambei (6 rather than 4-5), the frequency of isolated

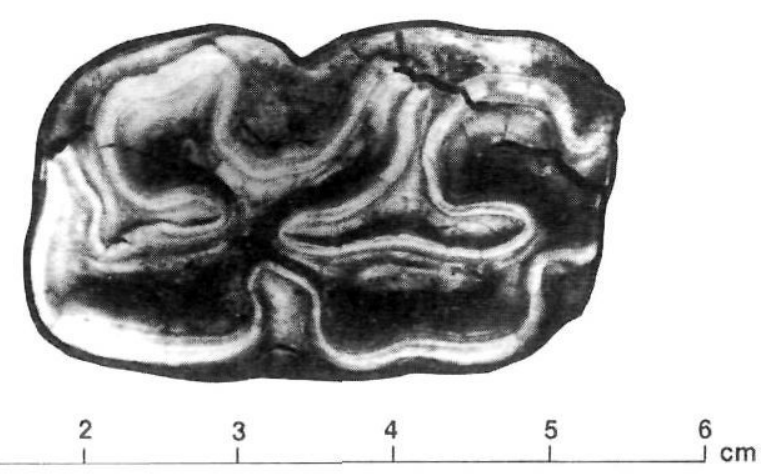

FIGURE 4. E. lambei: occlusal surface of lower cheektooth showing a typically caballoid entoflexid pattern.

Surface occlusive d'une dent jugale inférieure de E. lambei: exemple typique. 
hypoglyphs on $\mathrm{M}^{3}$ is much less (10.3\% rather than $47 \%$ ), the frequency of open post-fosettes on $\mathrm{M}^{3}$ is higher (34.5\% rather than $27 \%$ ) and the frequency of $\mathrm{dP}^{1}$ in adult specimens less (16\% instead of $25 \%$ ). These differences can probably be attributed to genetic differences between local populations or rather between the local population of E. lambei, at Bluefish, and the average values for E. przewalskii as sampled by Eisenmann. The variation in these qualitative characteristics for the two caballine groups observed here suggests that they may prove useful in distinguishing between caballine subspecies.

One further qualitative characteristic is observed: there is a basic difference in the shape of the entoflexid in lower teeth, between "U" pattern caballoids, which include $E$. caballus L., and "V" pattern stenonids, which include fossil stenonid horses (Equus stenonis Cocchi), E. zebra L., E. greyvi Oust., E. burchelli (Gray), E. asinus L., E. hemionus Pallas and E. kiang

TABLE ॥

Morphometric data for lower cheekteeth of E. lambei, Bluefish Caves

\begin{tabular}{|c|c|c|c|c|c|c|c|}
\hline & & $n$ & $\begin{array}{l}\text { Mean } \\
\text { values }\end{array}$ & Minimum & Maximum & $\mathrm{S}$ & V \\
\hline \multirow{6}{*}{ P2 } & $O L$ & 34 & 31.87 & 24.61 & 35.98 & 2.332 & 5.438 \\
\hline & AW & 34 & 12.47 & 10.49 & 14.79 & 0.969 & 0.939 \\
\hline & PW & 34 & 14.51 & 11.74 & 15.93 & 0.997 & 0.994 \\
\hline & $\mathrm{L}$ & 34 & 15.28 & 11.58 & 19.237 & 1.474 & 2.174 \\
\hline & $W(v)$ & 34 & 7.01 & 1.74 & 9.89 & 1.460 & 2.150 \\
\hline & Lpf & 34 & 15.51 & 4.50 & 18.84 & 1.863 & 3.474 \\
\hline \multirow{6}{*}{$\mathrm{P} 3 / 4$} & $\mathrm{OL}$ & 3 & 27.96 & 25.51 & 30.64 & 2.572 & 6.617 \\
\hline & AW & 3 & 16.62 & 15.41 & 18.34 & 1.530 & 2.343 \\
\hline & PW & 3 & 16.86 & 15.31 & 17.75 & 1.351 & 1.827 \\
\hline & $\mathrm{L}$ & 3 & 17.14 & 16.35 & 17.678 & 0.703 & 0.495 \\
\hline & $W(v)$ & 3 & 5.72 & 3.77 & 8.23 & 2.281 & 5.203 \\
\hline & Lpf & 3 & 13.89 & 11.36 & 16.56 & 2.602 & 6.774 \\
\hline \multirow{6}{*}{ M3 } & $\mathrm{OL}$ & 30 & 30.04 & 23.89 & 33.60 & 2.580 & 6.659 \\
\hline & AW & 30 & 13.39 & 10.32 & 15.71 & 1.186 & 1.408 \\
\hline & PW & 29 & 12.26 & 10.24 & 13.86 & 0.979 & 0.958 \\
\hline & L & 30 & 12.98 & 11.09 & 14.312 & 0.907 & 0.822 \\
\hline & $W(v)$ & 30 & 3.43 & 0.79 & 5.29 & 1.508 & 2.274 \\
\hline & Lpf & 30 & 11.13 & 8.13 & 12.76 & 1.216 & 1.480 \\
\hline \multirow{6}{*}{ P3 } & $\mathrm{OL}$ & 34 & 28.58 & 26.22 & 30.99 & 1.803 & 3.253 \\
\hline & AW & 34 & 15.69 & 12.60 & 18.09 & 1.167 & 1.364 \\
\hline & PW & 34 & 16.53 & 15.06 & 18.55 & 1.049 & 1.101 \\
\hline & $\mathrm{L}$ & 34 & 16.37 & 14.81 & 17.696 & 0.834 & 0.696 \\
\hline & $W(v)$ & 34 & 5.96 & 4.12 & 8.87 & 1.024 & 1.050 \\
\hline & Lpf & 34 & 14.54 & 11.77 & 16.45 & 1.163 & 1.353 \\
\hline \multirow{6}{*}{ P4 } & $\mathrm{OL}$ & 33 & 27.62 & 22.63 & 30.11 & 1.689 & 2.853 \\
\hline & $\mathrm{AW}$ & 33 & 15.86 & 9.88 & 18.96 & 1.737 & 3.020 \\
\hline & PW & 33 & 16.20 & 11.88 & 18.03 & 1.415 & 2.0 \\
\hline & $\mathrm{L}$ & 33 & 15.30 & 12.29 & 16.997 & 1.169 & 1.368 \\
\hline & $W(v)$ & 33 & 5.13 & 3.02 & 7.83 & 1.060 & 1.125 \\
\hline & Lpf & 33 & 12.70 & 5.38 & 16.61 & 2.179 & 4.749 \\
\hline \multirow{6}{*}{ M1 } & $\mathrm{OL}$ & 29 & 26.12 & 20.21 & 34.80 & 2.923 & 8.547 \\
\hline & $A W$ & 29 & 15.06 & 9.99 & 16.64 & 1.233 & 1.521 \\
\hline & PW & 29 & 14.24 & 11.02 & 16.06 & 1.096 & 1.202 \\
\hline & $\mathrm{L}$ & 29 & 13.75 & 11.38 & 14.927 & 0.881 & 0.777 \\
\hline & $W(v)$ & 29 & 2.74 & 1.32 & 5.91 & 1.212 & 1.469 \\
\hline & Lpf & 29 & 10.26 & 5.92 & 13.25 & 2.025 & 4.102 \\
\hline \multirow{6}{*}{ M2 } & $\mathrm{OL}$ & 28 & 26.70 & 22.48 & 32.35 & 2.278 & 5.190 \\
\hline & AW & 28 & 14.66 & 13.00 & 15.79 & 0.847 & 0.717 \\
\hline & PW & 28 & 14.04 & 11.26 & 16.54 & 1.126 & 1.268 \\
\hline & L & 28 & 13.71 & 12.22 & 14.688 & 1.205 & 1.452 \\
\hline & $W(v)$ & 28 & 2.77 & 1.00 & 7.73 & 1.456 & 2.120 \\
\hline & Lpf & 28 & 10.50 & 3.13 & 13.04 & 2.444 & 5.974 \\
\hline
\end{tabular}

Measurements are given in $\mathrm{mm} . \mathrm{s}$ 
Moorcr. (e.g., Eisenmann, 1981: Figs. 3, 4, 5; Forstén 1988b: 24). The Bluefish horses show a typically caballoid, "U" shaped entoflexid (Fig. 4).

Morphometric data from the present sample (Tables II and III) are graphically compared with mean values for $E$. przewalskii, E. caballus, E. kiang, E. hemionus, and E. asinus (Figs. 5, 6, 7 and 8). These data confirm that E. lambei resembles another Pleistocene caballoid, (viz., E. Przewalskin), rather than the stenonid group (of which E. kiang, E. hemionus, and $E$. asinus are part).
Eisenmann (1980) attributes taxonomic importance to the Index Protoconique (IP), defined as the ratio between the length of the protocone and the occlusal length of the tooth (Eisenmann, 1980: 82). IP values calculated here for E. lambei are slightly higher than the values calculated by Eisenmann (1980) for E. przewalskii, the wild horse (Fig. 7). The same relationship prevails between IP values within the tooth row, however. The higher IP values for $E$. lambei are a function of the longer protocone lengths $(\mathrm{PL})$ for this subspecies, and the smaller mean occlusal lengths of the teeth $(\mathrm{OL})$.

TABLE II

Morphometric data for upper cheekteeth of $\mathrm{E}$. lambei, Bluefish Caves

\begin{tabular}{|c|c|c|c|c|c|c|c|c|}
\hline & & & $n$ & Mean & Minimum & Maximum & $\mathrm{S}$ & V \\
\hline \multirow{5}{*}{ P2 } & OLC & OLe & 27 & 36.148 & 29.944 & 39.113 & 2.145 & 4.603 \\
\hline & LP & OW & 37 & 37.069 & 29.06 & 40.274 & 2.564 & 6.578 \\
\hline & IP & & 38 & 9.377 & 7.01 & 16.23 & 1.690 & 2.859 \\
\hline & & & 38 & 24.336 & 20.170 & 27.731 & 1.739 & 3.024 \\
\hline & & & 27 & 25.221 & 20.934 & 29.856 & 2.190 & 4.798 \\
\hline \multirow{5}{*}{ P3/P4 } & OLC & OLe & 2 & 26.878 & 26.697 & 27.058 & & \\
\hline & LP & OW & 2 & 26.907 & 26.907 & 27.124 & & \\
\hline & IP & & 2 & 15.321 & 14.117 & 16.525 & & \\
\hline & & & 2 & 28.109 & 28.109 & 28.384 & & \\
\hline & & & 2 & 56.976 & 56.976 & 61.073 & & \\
\hline \multirow{5}{*}{ M1/M2 } & OLC & OLe & 3 & 24.599 & 23.309 & 25.725 & 1.216 & 1.479 \\
\hline & LP & OW & 3 & 25.382 & 23.368 & 27.924 & 2.323 & 5.398 \\
\hline & IP & & 3 & 13.511 & 12.725 & 14.160 & 0.727 & 0.529 \\
\hline & & & 3 & 25.424 & 25.039 & 25.737 & 0.354 & 0.125 \\
\hline & & & 3 & 54.919 & 54.593 & 55.121 & 0.285 & 0.081 \\
\hline \multirow{5}{*}{ M3 } & OLC & OLe & 19 & 27.271 & 25.11 & 29.949 & 1.155 & 1.335 \\
\hline & LP & OW & 27 & 27.309 & 20.58 & 32.760 & 2.415 & 5.836 \\
\hline & IP & & 29 & 14.877 & 12.680 & 18.08 & 1.247 & 1.555 \\
\hline & & & 28 & 22.321 & 18.32 & 24.198 & 1.338 & 1.792 \\
\hline & & & 19 & 55.554 & 49.164 & 62.169 & 3.117 & 9.718 \\
\hline \multirow{5}{*}{ P3 } & OLC & OLe & 27 & 28.814 & 23.723 & 36.906 & 2.632 & 6.931 \\
\hline & LP & OW & 40 & 28.760 & 22.539 & 38.948 & 2.766 & 7.655 \\
\hline & IP & & 41 & 13.813 & 8.2 & 17.134 & 2.031 & 4.125 \\
\hline & & & 40 & 26.530 & 21.518 & 29.86 & 1.966 & 3.867 \\
\hline & & & 26 & 50.164 & 41.867 & 62.363 & 5.578 & 31.11 \\
\hline \multirow{5}{*}{ P4 } & OLC & OLe & 23 & 27.593 & 22.418 & 30.24 & 1.966 & 3.865 \\
\hline & LP & OW & 37 & 27.836 & 21.897 & 31.72 & 1.946 & 3.789 \\
\hline & IP & & 38 & 14.207 & 10.47 & 16.428 & 1.657 & 2.748 \\
\hline & & & 38 & 26.527 & 22.31 & 29.00 & 2.603 & 6.776 \\
\hline & & & 22 & 51.601 & 39.192 & 58.428 & 4.390 & 19.27 \\
\hline \multirow{5}{*}{ M1 } & OLC & OLe & 41 & 25.355 & 20.761 & 35.633 & 2.453 & 6.019 \\
\hline & LP & OW & 53 & 25.342 & 19.337 & 36.850 & 2.843 & 8.087 \\
\hline & IP & & 53 & 13.775 & 9.49 & 16.433 & 1.591 & 2.531 \\
\hline & & & 52 & 25.660 & 17.95 & 28.52 & 2.575 & 6.632 \\
\hline & & & 39 & 54.930 & 44.76 & 65.184 & 4.339 & 18.82 \\
\hline \multirow{5}{*}{ M2 } & OLC & OLe & 32 & 25.798 & 21.854 & 29.54 & 1.611 & 2.597 \\
\hline & LP & OW & 46 & 26.102 & 21.97 & 33.76 & 1.940 & 3.765 \\
\hline & IP & & 46 & 14.548 & 12.44 & 17.299 & 1.110 & 1.233 \\
\hline & & & 46 & 24.806 & 19.90 & 26.992 & 1.378 & 1.901 \\
\hline & & & 31 & 56.556 & 47.158 & 62.868 & 3.658 & 13.38 \\
\hline
\end{tabular}

Measurements are given in $\mathrm{mm} . \mathrm{s}$ 


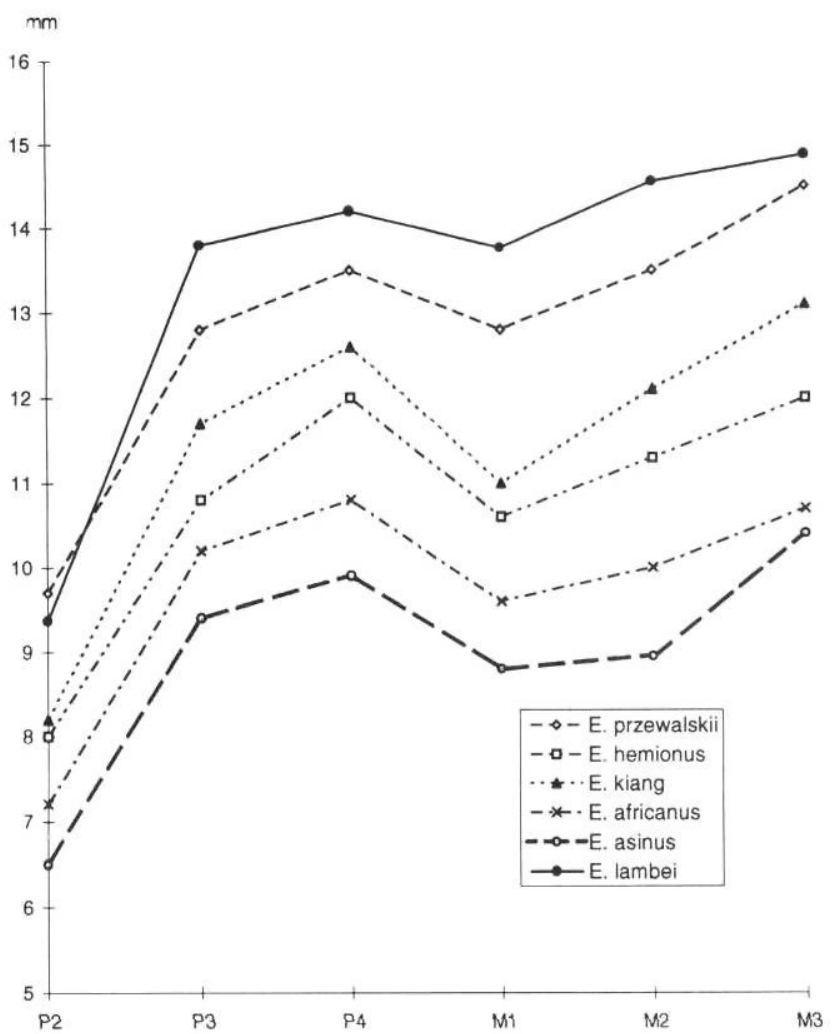

FIGURE 5. Mean protocone length of various equids: upper cheekteeth. After Eisenmann (1986).

Longueur moyenne du protocône chez diverses espèces d'équidés: dents supérieures (selon Eisenmann, 1986).

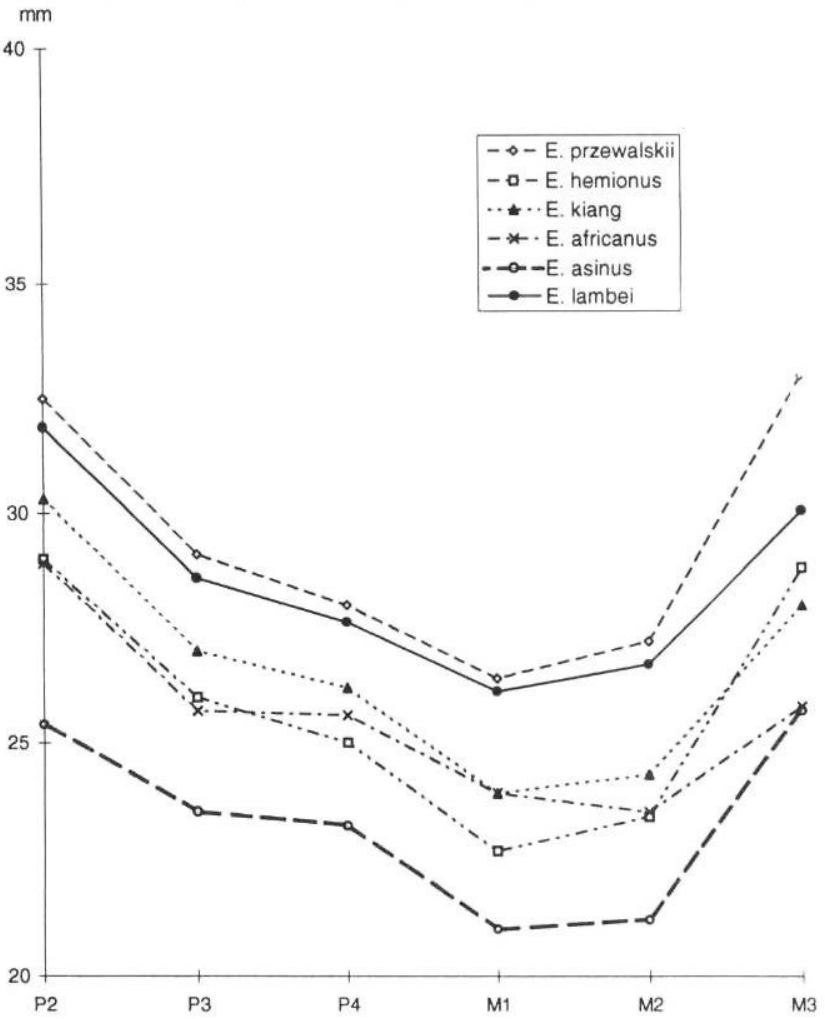

FIGURE 7. Mean occlusal length for the lower cheekteeth of various equids. After Eisenmann (1986).

Longueur occlusive moyenne, dents inférieures chez diverses espèces d'équidés (selon Eisenmann,1986).

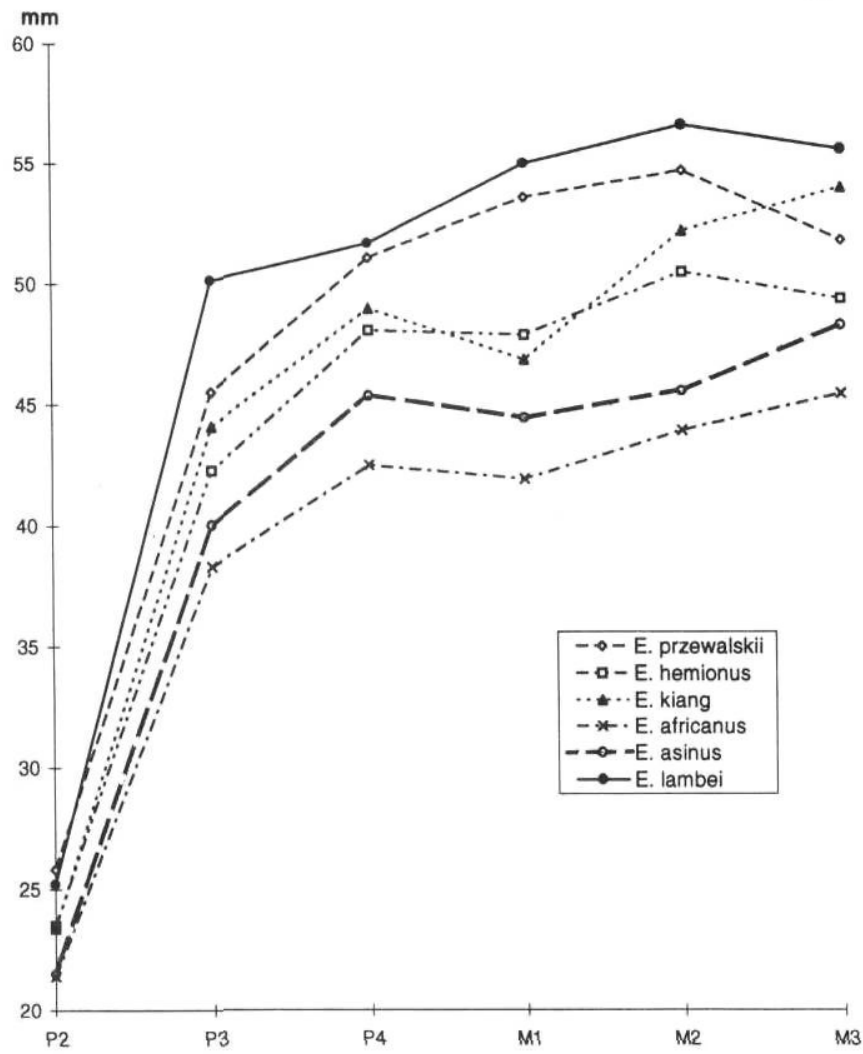

FIGURE 6. Mean protocone indices for various equids: upper cheekteeth. After Eisenmann (1986).

Indices moyens du protocône chez diverses espèces d'équidés dents supérieures (selon Eisenmann, 1986).

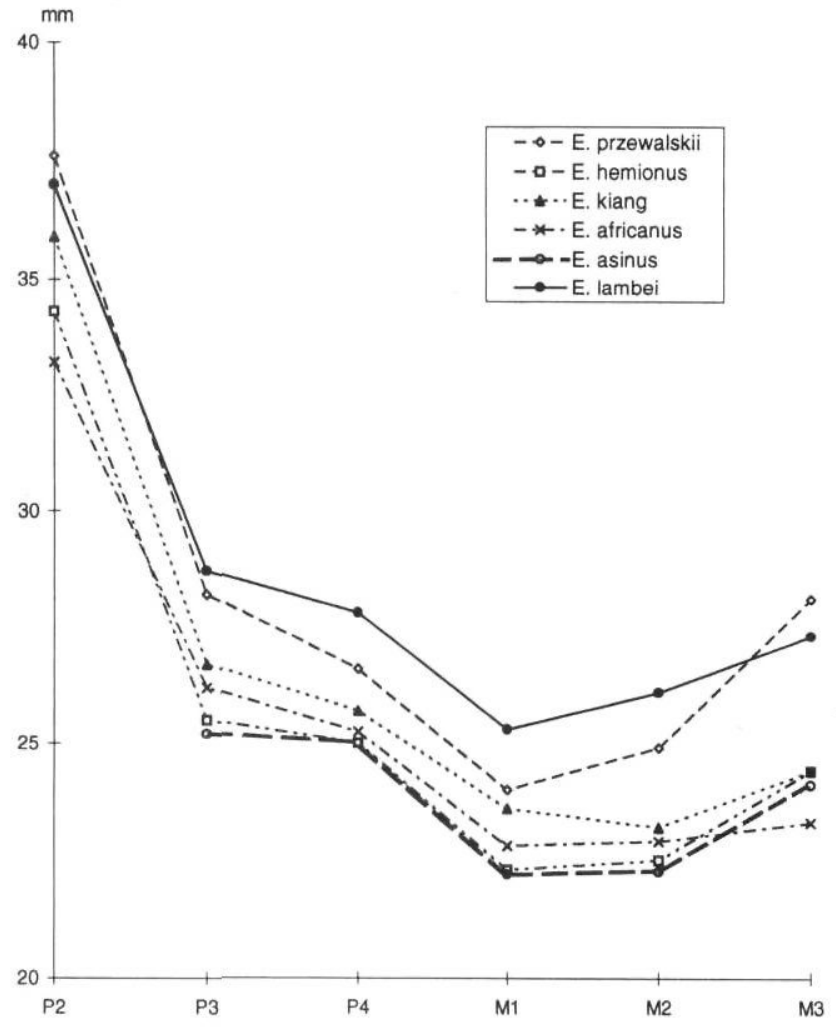

FIGURE 8. Mean occlusal length for the upper cheekteeth of various equids. After Eisenmann (1986).

Longueur occlusive moyenne, dents supérieures chez diverses espèces d'équidés (selon Eisenmann, 1986). 
TABLE IV

Cranial measurements of $\mathrm{E}$. lambei: overall length of the tooth rows, premolar and molar rows

Upper cheekteeth (see Figure 5 for measurements taken) :

\begin{tabular}{|c|c|c|c|c|}
\hline$N=19$ & $\begin{array}{c}\mathrm{OL}(\mathrm{mm}) \\
\text { Cheekteeth }\end{array}$ & $\begin{array}{c}\text { OL } \\
\text { Premolars }\end{array}$ & $\begin{array}{c}\text { OL } \\
\text { Molars }\end{array}$ & Notes \\
\hline 1. & 172.58 & 94.88 & 79.24 & \\
\hline 2. & 173.52 & 95.11 & 78.85 & \\
\hline 3. & 167.28 & 92.18 & 76.51 & \\
\hline 4. & & & 78.14 & missing $M$ \\
\hline 5. & 172.66 & 95.02 & 79.43 & \\
\hline 6. & & & 78.56 & \\
\hline 7. & & $(92.90)$ & & deciduous \\
\hline 8. & & (92.65) & & deciduous \\
\hline 9. & 164.72 & 96.02 & 72.14 & \\
\hline 10. & (180.53) & $(102.58)$ & & (incl. dP1) \\
\hline 11. & 175.02 & 98.91 & 77.89 & \\
\hline 12. & 170.25 & 95.18 & 75.78 & \\
\hline 13. & 167.72 & 92.12 & 76.86 & \\
\hline 14. & 168.35 & 92.44 & 76.02 & \\
\hline 15. & 162.47 & 92.31 & 70.33 & \\
\hline 16. & 167.96 & 90.65 & 76.52 & \\
\hline 17. & 168.83 & 93.11 & 75.97 & \\
\hline 18. & & 90.83 & & PMs only \\
\hline 19. & 167.11 & 92.98 & missing M1 & senescent \\
\hline Average & $(N=13)$ & $(\mathrm{N}=14)$ & $(\mathrm{N}=14)$ & \\
\hline values & 168.80 & 93.69 & 76.59 & \\
\hline
\end{tabular}

Tooth row lengths: Lower cheekteeth (see Figure 7 for measurements taken) :

\begin{tabular}{|c|c|c|c|c|}
\hline $\mathrm{N}=17$ & $\begin{array}{c}\mathrm{OL}(\mathrm{mm}) \\
\text { Cheekteeth }\end{array}$ & $\begin{array}{c}\text { OL } \\
\text { Premolars }\end{array}$ & $\begin{array}{c}\text { OL } \\
\text { Molars }\end{array}$ & Notes \\
\hline 1. & 170.22 & 87.08 & 82.43 & \\
\hline 2. & 168.55 & 95.10 & 76.78 & M3 erupting \\
\hline 3. & & 92.11 & & M3 absent \\
\hline 4. & 166.48 & 86.08 & 80.61 & \\
\hline 5. & 163.57 & 85.51 & 79.56 & senescent \\
\hline 6. & 171.41 & 93.69 & 77.80 & M3 just worn \\
\hline 7. & 166.26 & 88.64 & 76.84 & \\
\hline 8. & 176.29 & 92.24 & 82.25 & \\
\hline 9. & 165.36 & 87.52 & 78.95 & \\
\hline 10. & 166.76 & 87.63 & 80.69 & \\
\hline 11. & & & 80.57 & missing PM \\
\hline 12. & 166.32 & 86.79 & 80.69 & \\
\hline 13. & 169.50 & 88.96 & 80.85 & \\
\hline 14. & & & 74.72 & missing P2 \\
\hline 15. & 167.96 & 84.70 & 79.70 & large (PM) interstices \\
\hline 16. & 168.30 & 87.08 & 79.94 & \\
\hline 17. & 170.92 & 87.76 & 81.70 & \\
\hline Average & $(\mathrm{N}=14)$ & $(\mathrm{N}=15)$ & $(N=16)$ & \\
\hline values & 168.42 & 88.73 & 79.6 & \\
\hline
\end{tabular}

Measurements given in mm.s. 
The presence of relatively long protocones is considered by Eisenmann (1980: 105) to be characteristic of modern horses in general and E. przewalskii in particular. It is interesting that $E$. caballus from Liakhov Islands, a small, Siberian contemporary of $E$. lambei, has relatively high IP values (Eisenmann, 1980: 125), especially on the molars. The similarity between this equid and $E$. lambei is therefore noted here. It should also be noted that Forsten (1982) considers the protocone index (ff. Eisenmann, 1980, 1986) invalid for taxonomic characterisations because of: 1) size differences observable within the same subspecies of horse; and 2) allometric associations between the recorded dimensions and overall body size. The authors tend to agree with Forsten with regards to the taxonomic usefulness of the IP. We are primarily interested in its potential allometric use.

Further quantitative measurements presented here (Table IV) include overall length of the tooth row (OL), and length of the molar and premolar rows. Measurements were taken following Von den Driesch (1976) and are illustrated in Figures 2 and 3 .

\section{CANINE TEETH}

The skeletons of modern horses are virtually the same except for the presence of canine teeth in males and relatively smaller or absent canines in females (Berger, 1986: 21). This means that canine teeth are one of the few qualitative characteristics which may be used to reconstruct socionomic ratios in fossil populations (MacFadden, 1992: 272-273). MacFadden (1992: 273) states that: "With sufficiently large and well-preserved samples, canine dimorphism is seen to have been common in virtually all extinct horses".

Many horses in the Bluefish fauna have large, well-developed canines ${ }^{1}$ (Fig. 9). In Cave I, only one adult anterior jaw is present and it contains a well-developed canine. In Cave II, 3 of 5 adult anterior jaws contain well-developed canines. In Cave III, 11 out of 14 anterior jaws (of which 2 are immature) contain canines, i.e. 11 out of 12 adult anterior jaws have well-developed canine teeth (Table V). Several possibilities are raised by these data: 1) a succession of small bachelor bands came to grief near the caves; 2) selective predation upon adult males was taking place; 3 ) retention of canines in females is a characteristic of E. lambei, in which case the presence of canine teeth cannot be used to infer sex ratios for this subspecies.

Horse herds live either in family bands composed of an adult male, and females with their foals, or in bachelor bands: small, unstable groups of fewer than four young males (Waring, 1983: 142). In Caves II and III yearlings are present in the death assemblage, which points to the presence of some family bands rather than only bachelor bands - weakening the case for option 1. A pattern of selective predation of adult male horses at Bluefish (option 2) is unexpected, given the large number of different-sized predators active in the vicinity of the caves (Cinq-Mars, 1990). Of the three options, therefore, option 3 seems a plausible explanation of

1. The canine teeth were not measured, as this would have necessitated removal from the jaws.

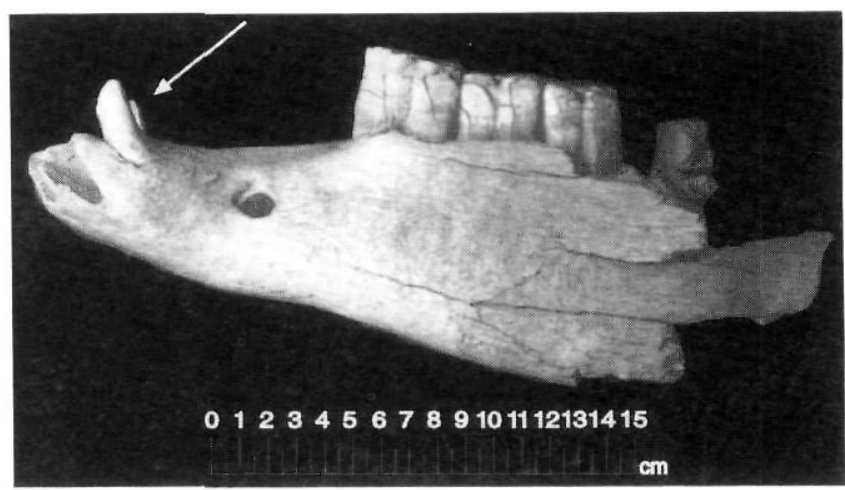

FIGURE 9. Mandible of E. lambei (Bluefish Caves) showing typically well-developed canines, potentially characteristic of the species.

Mandibule de E. lambei (grottes du Poisson Bleu) comprenant des canines bien développées, probablement caractéristiques de l'espèce.

the observed ratio of jaws with and without canine teeth. In which case, canine teeth would be characteristic of both males and females in E. lambei. If large canines are characteristic of both sexes in E. lambei, as the data suggest, this could indicate the retention of a primitive trait, shared with $E$. stenonis (Prat, 1976: 409).

A brief survey by one of us (Burke), of specimens of $E$. lambei from fossil localities in Yukon and Alaska, held at the Canadian Museum of Nature, indicates a high incidence of canines from other fossil localities.

\section{DISCUSSION: IMPLICATIONS OF THE METRICAL INFORMATION}

According to Forstén (1993:71) Late Pleistocene horses in northern environments in North America were smaller than their southern contemporaries. On another scale, the muzzle reduction (and a wide choanae) in $E$. lambei, is attributed by Eisenmann (1986: 72) to an adaptation to cold conditions during the Late Pleistocene.

Guthrie (1985b, as cited in Forstén 1993:70) interpreted size reduction in Late Pleistocene non-ruminants (such as the horse) in northern environments as the result of a shortened growth season, conferring an adaptive disadvantage on the conservative growth strategies of non-ruminants such as horse. Forstén (1993: 71) suggests that body-size reduction in Late Pleistocene caballoids may have had the effect of reducing the gestation period and keeping population size high enough to allow the species to adapt to an unpredictable, glacial environment.

The size/climate association is not perfect. The average body size of $E$. conversidens is about the same as that of $E$. lambei (C.R. Harington, pers. comm., 1995). Furthermore, as in the Late Pleistocene fossil record of Europe, a relatively large subspecies of horse is also found in Late Pleistocene deposits in the Yukon (C.R. Harington pers. comm., 1994). And as Forstén herself (1993:72) points out, size reduction in caballoids set in before the rapid climatic changes at the end of the Late Pleistocene. Previous climatic changes (shifts from glacial to interglacial conditions) occurred during the Middle Pleistocene without affecting equid body-size (supra). 
TABLE V

Incidence of canine teeth in $\mathrm{E}$. lambei from the Bluefish Cave assemblages

\begin{tabular}{|c|c|c|c|c|}
\hline & Cave & $U / L$ & $\mathrm{C} 1$ & Status \\
\hline $\mathrm{G} 7(\mathrm{E} 1 / 2)-8-1$ & 1 & $U$ & $Y$ & well-developed, worn \\
\hline $2-\mathrm{H} 5-?$ & 2 & $\mathrm{~L}$ & $Y$ & erupting \\
\hline B3-3-23 & 2 & L & $\mathrm{N}$ & \\
\hline C3(E0-3-19) & 2 & $\mathrm{~L}$ & $\mathrm{~N}$ & \\
\hline $\mathrm{H} 6-3-14$ & 2 & L & $Y$ & vestigial \\
\hline H6-6-15 & 2 & L & Y & juvenile/alveola present \\
\hline $15(E)-3-9$ & 2 & $U$ & $\mathrm{Y}$ & well developed \\
\hline $85-76$ & 3 & $\mathrm{~L}$ & Y & well developed \\
\hline 85-109 & 3 & $L$ & Y & well developed \\
\hline $85-90$ & 3 & $\mathrm{~L}$ & Y & well developed \\
\hline $85-76^{*}$ & 3 & $\mathrm{~L}$ & Y & no tooth/alveola present \\
\hline S-3-89 & 3 & $\mathrm{~L}$ & $Y$ & senescent/vestigial \\
\hline$M-9-132$ & 3 & $\mathrm{~L}$ & $Y$ & well developed \\
\hline T.P.1-D-22 & 3 & $\mathrm{~L}$ & $\mathrm{~N}$ & \\
\hline$M-9-136$ & 3 & U & $Y$ & alveola present \\
\hline M-9-97 & 3 & $\mathrm{~L}$ & $\mathrm{~N}$ & juvenile \\
\hline $85-95$ & 3 & $\mathrm{~L}$ & $Y$ & well developed \\
\hline $85-81$ & 3 & $\mathrm{~L}$ & $Y$ & erupting \\
\hline$M-9-138 a$ & 3 & $\mathrm{~L}$ & $Y$ & well developed \\
\hline 1993 nettoyage & 3 & $U$ & $Y$ & well developed \\
\hline $85-89$ & 3 & $\mathrm{~L}$ & $\mathrm{~N}$ & juvenile \\
\hline
\end{tabular}

Summary :

\begin{tabular}{lcll}
\hline & Pres. & Abs. & juvenile \\
\hline Cave 1 & $1 / 1$ & $0 / 1$ & $0 / 1$ \\
Cave 2 & $3 / 6$ & $2 / 6$ & $1 / 6$ \\
Cave 3 & $11 / 14$ & $1 / 14$ & $2 / 14$
\end{tabular}

N.B. Upper and lower incisor rows only were used in this table (complete and partial)

Perhaps size reduction in northern caballoids relative to earlier equids in North America, and other Late Pleistocene equids in the south, resulted from rapid environmental change. If so, it seems unreasonable to expect a relative size difference between $E$. lambei, a northern Late Pleistocene equid, and Late Pleistocene equids living in more favourable conditions in Europe.

Tooth size may be used as a measure of body-size in horses, according to some authors (e.g., as suggested in MacFadden, 1992: 269). This simple association is not without criticism, however. For example, Nobis (1971) suggests that modifications in tooth size may not have been synchronous with changes in overall body-size. More frequently therefore, tooth size is used in combination with size of the third metacarpal and phalange (e.g., Forstén, 1990). A comparison of mean tooth sizes is presented here, however, as a preliminary step in assessing body size of $E$. lambei prior to obtaining information on MC-III and phalange size for the Bluefish equids (Harington, in prep.).

Tooth size on two dimensions, overall tooth width (OW) and occlusal length (OLe), for E. lambei is compared here with the means from Eisenmann for $E$. caballus and $E$.

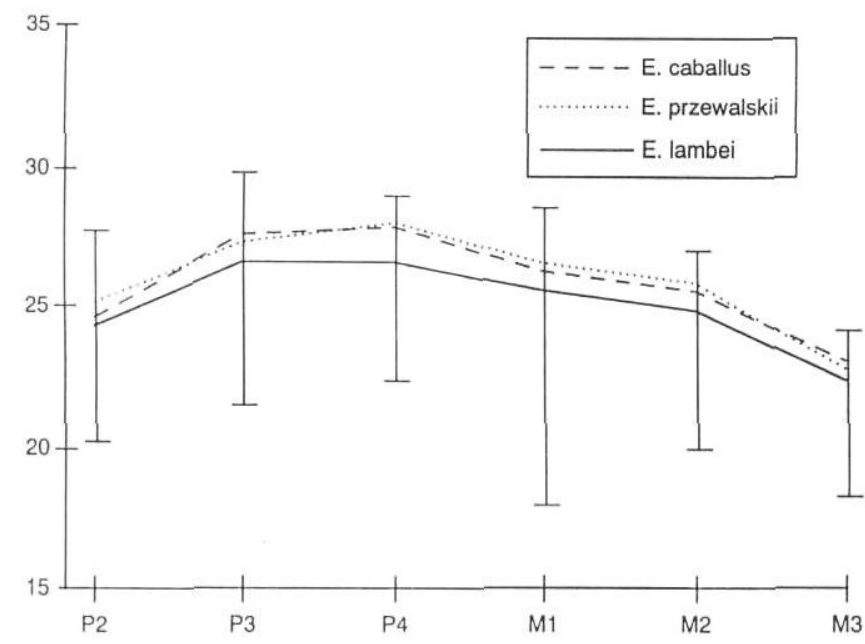

FIGURE 10. Comparison of mean occlusal tooth widths for $E$. caballus, E. przewalskii, and E. ambei.

Comparaison de la largeur moyenne des dents de E. caballus, E. przewalskii et E. ambei.

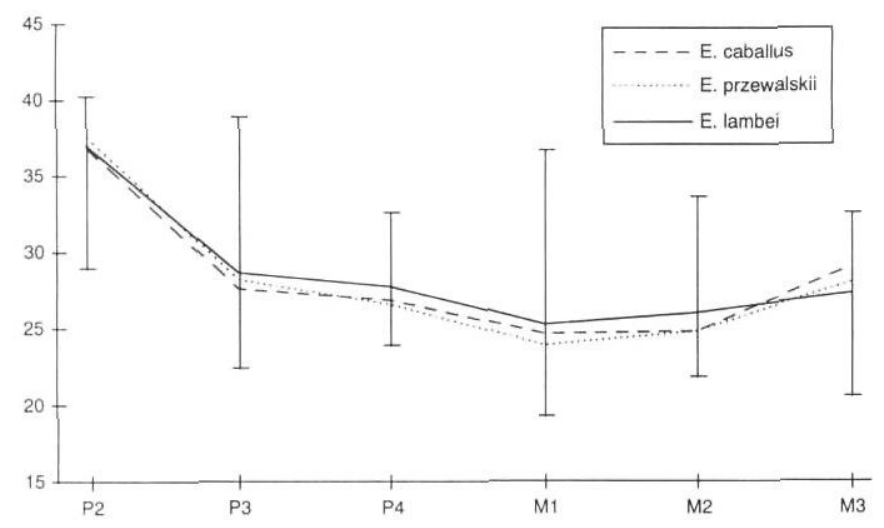

FIGURE 11. Comparison of mean occlusal tooth lengths for $E$. caballus, E. przewalskii, and E. lambei.

Comparaison de la longueur moyenne des dents de E. caballus, E. przewalskii et $\mathrm{E}$. ambei.

przewalskii $(1980 ; 1986)$. The comparison indicates that the dentition of $E$. lambei from Bluefish is not smaller than these contemporary European horses. All values for E. lambei fall within one standard deviation of Eisenmann's values (Figs. 10 and 11). Mean occlusal lengths (OLe) and tooth widths (OW) of $E$. lambei are lower than the means reported in Eisenmann (1980: Table 46; 1986) for E. przewalskii and $E$. caballus, except for occlusal length of $\mathrm{P}^{2}$ (Figs. 10 and 11), but fall within one standard deviation of Eisenmann's mean values. The standard deviation for $E$. lambei $\mathrm{P}^{2}$ occlusal length overlaps Eisenmann's values.

Forstén (1991: fig. 4), measuring occlusal length, has detected an apparent chronological trend toward tooth size reduction in some local European samples of Equus. A comparison of occlusal length (OLe) values for $E$. lambei with the values for mesio-distal length (Levine, 1982: table 1) for Upper Pleistocene fossil populations of Western European horses, shows that the Bluefish population is not significantly 
TABLE VI

A comparison of size differences estimated occlusal length (OLe) between E. lambei and European Upper Pleistocene horses reported in Levine (1982: 232).

\begin{tabular}{|c|c|c|c|c|c|c|c|}
\hline $\begin{array}{l}\text { Tooth } \\
\text { element }\end{array}$ & $\begin{array}{l}\text { Height } \\
(\mathrm{mm})\end{array}$ & $\begin{array}{l}\text { Mean OLe } \\
\text { E. lambei } \\
(\mathrm{mm})\end{array}$ & $\begin{array}{l}\text { Standard } \\
\text { deviation } \\
\text { E. lambei }\end{array}$ & $\begin{array}{c}\mathrm{N} \\
\text { E. lambei } \\
\text { sample }\end{array}$ & $\begin{array}{c}\mathrm{N} \\
\text { Levine } \\
\text { sample }\end{array}$ & $\begin{array}{l}\text { Mean OLe } \\
\text { Levine } \\
\text { sample }\end{array}$ & $Z^{*}$ \\
\hline $\mathrm{P}^{2}$ & $35-40$ & 37.6 & 1.64 & $\mathrm{~N}=5$ & $\mathrm{~N}=14$ & 37.4 & -0.09 \\
\hline $\mathrm{P}^{3}$ & $\begin{array}{l}35-40 \\
45-50 \\
65-70\end{array}$ & $\begin{array}{l}29.8 \\
27.5 \\
29.4\end{array}$ & $\begin{array}{l}4.32 \\
\text { NS* }^{*} \\
\text { NS }\end{array}$ & $\begin{array}{l}\mathrm{N}=6 \\
\mathrm{~N}=2 \\
\mathrm{~N}=2\end{array}$ & $\begin{array}{l}N=9 \\
N=17 \\
N=10\end{array}$ & $\begin{array}{l}29.9 \\
30.2 \\
31.4\end{array}$ & $\begin{array}{l}0.02 \\
\text { NS } \\
\text { NS }\end{array}$ \\
\hline$P^{4}$ & $\begin{array}{l}45-50 \\
75-80\end{array}$ & $\begin{array}{l}25.8 \\
28.7\end{array}$ & $\begin{array}{l}\text { NS } \\
\text { NS }\end{array}$ & $\begin{array}{l}N=1 \\
N=1\end{array}$ & $\begin{array}{l}\mathrm{N}=12 \\
\mathrm{~N}=10\end{array}$ & $\begin{array}{l}28.7 \\
29.8\end{array}$ & $\begin{array}{l}\text { NS } \\
\text { NS }\end{array}$ \\
\hline$M^{\prime}$ & $\begin{array}{l}35-40 \\
40-45 \\
65-70 \\
70-75\end{array}$ & $\begin{array}{l}24.0 \\
24.2 \\
25.6 \\
26.8\end{array}$ & $\begin{array}{l}0.99 \\
\text { NS } \\
0.69 \\
0.65\end{array}$ & $\begin{array}{l}N=6 \\
N=3 \\
N=5 \\
N=3\end{array}$ & $\begin{array}{l}N=7 \\
N=16 \\
N=16 \\
N=5\end{array}$ & $\begin{array}{l}25.8 \\
25.7 \\
27.4 \\
28.3\end{array}$ & $\begin{array}{l}1.82 \\
\text { NS } \\
2.61 \\
\text { NS }\end{array}$ \\
\hline $\mathrm{M}^{2}$ & $\begin{array}{l}45-50 \\
70-75 \\
75-80\end{array}$ & $\begin{array}{l}24.6 \\
26.1 \\
26.8\end{array}$ & $\begin{array}{l}\text { NS } \\
0.12 \\
0.47\end{array}$ & $\begin{array}{l}N=1 \\
N=3 \\
N=4\end{array}$ & $\begin{array}{l}N=5 \\
N=9 \\
N=3\end{array}$ & $\begin{array}{l}27.7 \\
26.9 \\
28.4\end{array}$ & $\begin{array}{l}\text { NS } \\
\text { NS } \\
3.36\end{array}$ \\
\hline $\mathrm{M}^{3}$ & $\begin{array}{l}25-30 \\
40-45\end{array}$ & $\begin{array}{l}29.0 \\
26.1\end{array}$ & $\begin{array}{l}\text { NS } \\
\text { NS }\end{array}$ & $\begin{array}{l}N=1 \\
N=2\end{array}$ & $\begin{array}{l}N=5 \\
N=1\end{array}$ & $\begin{array}{l}27.6 \\
25.7\end{array}$ & $\begin{array}{l}\text { NS } \\
\text { NS }\end{array}$ \\
\hline $\mathrm{P}_{2}$ & $\begin{array}{l}25-30 \\
30-35 \\
45-50 \\
50-55\end{array}$ & $\begin{array}{l}32.2 \\
34.2 \\
32.8 \\
33.2\end{array}$ & $\begin{array}{l}\text { NS } \\
\text { NS } \\
2.26 \\
\text { NS }\end{array}$ & $\begin{array}{l}N=2 \\
N=1 \\
N=5 \\
N=2\end{array}$ & $\begin{array}{l}N=1 \\
N=5 \\
N=9 \\
N=3\end{array}$ & $\begin{array}{l}30.1 \\
31.1 \\
31.7 \\
31.8\end{array}$ & $\begin{array}{c}\text { NS } \\
\text { NS } \\
-0.49 \\
\text { NS }\end{array}$ \\
\hline$P_{3}$ & $\begin{array}{l}30-35 \\
65-70\end{array}$ & $\begin{array}{l}27.7 \\
28.8\end{array}$ & $\begin{array}{l}\text { NS } \\
\text { NS }\end{array}$ & $\begin{array}{l}\mathrm{N}=3 \\
\mathrm{~N}=3\end{array}$ & $\begin{array}{l}N=1 \\
N=3\end{array}$ & $\begin{array}{l}25.0 \\
29.0\end{array}$ & $\begin{array}{l}\text { NS } \\
\text { NS }\end{array}$ \\
\hline$P^{4}$ & $\begin{array}{l}35-40 \\
40-45 \\
75-80\end{array}$ & $\begin{array}{l}27.7 \\
26.8 \\
28.6\end{array}$ & $\begin{array}{l}\text { NS } \\
\text { NS } \\
\text { NS }\end{array}$ & $\begin{array}{l}N=1 \\
N=2 \\
N=2\end{array}$ & $\begin{array}{l}N=5 \\
N=1 \\
N=9\end{array}$ & $\begin{array}{l}26.5 \\
24.1 \\
27.0\end{array}$ & $\begin{array}{l}\text { NS } \\
\text { NS } \\
\text { NS }\end{array}$ \\
\hline$M_{1}$ & $\begin{array}{l}35-40 \\
65-70\end{array}$ & $\begin{array}{l}24.2 \\
26.9\end{array}$ & $\begin{array}{l}\text { NS } \\
0.73\end{array}$ & $\begin{array}{l}\mathrm{N}=2 \\
\mathrm{~N}=4\end{array}$ & $\begin{array}{l}N=1 \\
N=9\end{array}$ & $\begin{array}{l}23.2 \\
27.0\end{array}$ & $\begin{array}{l}\text { NS } \\
0.14\end{array}$ \\
\hline $\mathrm{M}_{2}$ & $\begin{array}{l}40-45 \\
75-80\end{array}$ & $\begin{array}{l}24.9 \\
30.8\end{array}$ & $\begin{array}{l}\text { NS } \\
\text { NS }\end{array}$ & $\begin{array}{l}\mathrm{N}=2 \\
\mathrm{~N}=2\end{array}$ & $\begin{array}{l}N=1 \\
N=9\end{array}$ & $\begin{array}{l}23.8 \\
27.7\end{array}$ & $\begin{array}{l}\text { NS } \\
\text { NS }\end{array}$ \\
\hline $\mathrm{M}_{3}$ & $\begin{array}{l}35-40 \\
45-50\end{array}$ & $\begin{array}{l}33.6 \\
31.06\end{array}$ & $\begin{array}{l}\text { NS } \\
\text { NS }\end{array}$ & $\begin{array}{l}N=1 \\
N=1\end{array}$ & $\begin{array}{l}N=5 \\
N=1\end{array}$ & $\begin{array}{l}32.0 \\
27.9\end{array}$ & $\begin{array}{l}\text { NS } \\
\text { NS }\end{array}$ \\
\hline
\end{tabular}

* NS= insufficient sample size

different from Late Pleistocene, Western European caballoids in four out of seven measurements (Table VI). Levine's (1979, 1982) fossil population comprises 65 "assemblage units", representing either distinct stratigraphic units from within a site, or entire site assemblages where the site was excavated in a single unit (e.g., at Jaurens). Sites sampled by the author (Levine, 1979:120, table 19) include: Jaurens; Solutre; Combe Grenal; Arlay; Gigny; and Roc de Marsal, among others.

Occlusal length (OLe) at specific tooth-height intervals for each anatomical position for $E$. lambei were compared with Levine's fossil sample (ff. Levine, 1982). Of 37 categories recorded by Levine (1982: table 1), only seven could be compared due to insufficient sample sizes. Of these, four produced $Z$-scores (deviation from the mean in standard deviations) within one standard deviation of the European fossil sample; one was within two standard deviations and two were more than two standard deviations from the European fossil sam- ple (Table VI). Unfortunately, size trends through time such as detected by Forstén (1991) cannot be confirmed at Bluefish due to the undifferentiated nature of the stratigraphy from about $15,000 \mathrm{BP}$ to the Holocene boundary.

\section{CONCLUSION}

We confirm the identification of $E$. lambei as a caballine horse. Tooth dimensions of $E$. lambei also indicate its resemblance to $E$. caballus from the Liakhov Islands, Siberia. This enables us to propose palaeoethological reconstructions for $E$. lambei in areas of archaeological interest such as the Bluefish Caves (Burke and Cinq-Mars, in prep.). Both caballoids and stenonids inhabit steppe-like, or savannah-like regions (Berger, 1986) and are non-selective grazers capable of enduring a wide variety of climatic conditions. The principal differences between the caballines and stenonids today lies in their social organization and migration patterns. Caballoids 
form small, stable bands of four to ten individuals, whereas stenonids typically do not. Furthermore, modern stenonids migrate in large herds, whereas few caballoids have been observed to do so.

The high ratio of canine teeth in the Bluefish assemblages is either the result of the sampling of more bachelor herds than family herds, or is a genetic trait (retention of canines in females). If this last is true, it could be a useful trait in discriminating $E$. lambei from other Late Pleistocene horses.

E. lambei is similar in size to Late Pleistocene caballoids from Western Europe, as well as to modern caballoids, based on tooth dimensions. This conclusion remains to be tested using metrical data from the post-cranial material excavated at Bluefish caves, specifically MC-III and phalange size (Harington, work in progress). If it is supported by the postcranial data, this fact has implications for the possible association of body-size in Late Pleistocene equids with environmental conditions. Climatic conditions in eastern Beringia were arguably more critical for horses at the close of the Pleistocene than conditions in Western Europe, and certainly more severe than in Europe today, and yet body size (as measured by tooth dimensions) in $E$. lambei does not appear to reflect this difference in a significant way. However, environmental conditions cannot be the sole factor regulating body-size in equids, and there is no need to postulate that size trends in equids are a unified phenomenon. That is, equid size reduction may not have occurred to the same extent, or for the same reasons, in North America and in Europe.

\section{ACKNOWLEDGEMENTS}

The authors gratefully acknowledge the significant contribution made by C.R. Harington (Canadian Museum of $\mathrm{Na}$ ture) to this work. V. Eisenmann also provided useful comments on an earlier draft of this paper. Any errors or ommissions remaining in the text are the sole responsibility of the authors. The laboratory component of this research was supported by a Postdoctoral Fellowship from the Social Sciences and Humanities Research Council of Canada to Burke, and by the Canadian Museum of Civilization. The field component was carried out by Cinq-Mars with the financial and logistic support of the Archaeological Survey of Canada, Canadian Museum of Civilization, and the Polar Continental Shelf Project, Natural Resources Canada. The discovery and earliest investigations at Bluefish Caves were made possible with the assistance of the Social Sciences and Humanities Research Council of Canada. We especially want to acknowledge the help provided by numerous colleagues and field assistants, as well as that of the numerous Vuntut Gwichin residents of Old Crow who greatly facilitated research.

Radiocarbon dates were obtained thanks to the support of: Dr. R.W. Brown (Atomic Energy of Canada, Ltd.); Dr. W. Blake (Geological Survey of Canada) and Dr. E. Nelson (Simon Fraser University) and colleagues.

\section{REFERENCES}

Azzaroli, A., 1990. The Genus Equus in Europe. In E.H. Lindsay et al., eds, European Neogene Mammal Chronology. Plenum Press, New York.
Berger, J., 1986. Wild horses of the Great Basin. University of Chicago Press, Chicago.

Burke, A. and Cinq-Mars, J., in prep. Palaeoethological reconstructions and mortality profiles of Equus lambei from the Bluefish Caves, Yukon Territory, Canada.

Cinq-Mars, J., 1990. La place des grottes du Poisson Bleu dans la préhistoire Béringienne. Revista de Arqueologia Americana, 1: 9-32.

Eisenmann, V., 1980. Les chevaux (Equus sensu lato) fossiles et actuels: cranes et dents jugales. Éditions du CNRS, Paris.

- 1986. Comparative Osteology of Modern and Fossil Horses, Half-asses, and Asses, p. 67-116. In R.H. Meadow and H.-P. Uerpmann, eds., Equids in the Ancient World. Dr. Ludwig Reichart Verlag, Wiesbaden.

1991. Les chevaux quaternaires européens (Mammalia, Périssodactyla) taille, typologie, biostratigraphie et taxonomie. Géobios, 24(6): 747-759.

Forstén, A., 1982. Indices in equid systematics and phylogeny. Annales Zoologici Fennici, 19: 183-191.

1988a. The small caballoid horse of the Upper Pleistocene and Holocene. Journal of Animal Breeding and Genetics, 105: 161-176.

1988b. Middle Pleistocene replacement of stenonid horses by caballoid horses- Ecological Implications. Palaeogeography, Palaeoclimatology, Palaeoecology, 65: 23-33.

1991. Size decrease in Pleistocene-Holocene true or caballoid horses of Europe. Mammalia, 55(3): 407-419.

1993. Size decrease in Late Pleistocene-Holocene caballoid horses (Genus Equus) intra- or interspecific evolution? A discussion of alternatives. Quaternary International 19: 71-75.

Groves, C., 1974. Horses, Asses and Zebras in the Wild. David and Charles, London.

Groves, C. and Mazak, V., 1967. On some taxonomic problems of Asiatic wild asses; with the description of a new subspecies (Perissodactyla; Equidae). Saugertierkunde, 32: 321-355.

Guthrie, R.D., 1982. Mammals of the Mammoth Steppe as paleoenvironmental indicators, p. 308-326. In D.M Hopkins et al., eds., Paleoecology of Beringia. Academic Press, New York.

1985a. Woolly Arguments Against the Mammoth Steppe. A New Look at the Palynological Data. Quarterly Review of Archaeology, 6: 9-16.

1985b. Alaskan megabucks, megabulls and megarams: The issue of Pleistocene gigantism. Carnegie Museum of Natural History, Special Publication, 8: 482-510.

Harington, C.R., 1977. Pleistocene Mammals of the Yukon Territory. Ph.D. dissertation, Dept. of Zoology, University of Alberta, Edmonton.

1978. Quaternary Vertebrate Faunas of Canada and Alaska and their Suggested Chronological Sequence. National Museum of Canada, Syllogeus 15, Ottawa, $105 \mathrm{p}$.

1980. Pleistocene mammals from Lost Chicken Creek, Alaska. Canadian Journal of Earth Sciences, 17: 168-198.

- 1989. Pleistocene vertebrate localities in the Yukon, p. 93-98 In L.D. Carter, T. Hamilton and J.P. Galloway, eds., Late Cenozoic History of the Interior Basins of Alaska and the Yukon. U.S. Geological Survey Circular 1026.

Harington, C.R. and Clulow F.V., 1973. Pleistocene mammals from Gold Run Creek, Yukon Territory. Canadian Journal of Earth Sciences, 10(5): 697759.

Hay, O.P., 1917. Description of a new species of extinct horse, Equus lambei, from the Pleistocene of Yukon Territory. Proceedings of the U.S. National Museum (Smithsonian Institution), 53: 435-443.

Hughes, O.L., Harington, C.R., Janssens, J.A., Matthews, J.V. Jr., Morlan, R.E., Rutter, N.W. and Schweger, C.E., 1981. Upper Pleistocene stratigraphy, paleoecology, and archaeology of the Northern Yukon Interior, Eastern Beringia, 1. Bonnet Plume Basin. Arctic, 34(4): 329-265.

Irving, W.N., Jopling, A.V. and Kritsch-Armstrong, I., 1989. Studies of bone technology and taphonomy, Old Crow Basin, Yukon Territory, p. 347-379. In R. Bonnichsen and M.H. Sorg, eds., Bone Modification. Center for the Study of the First Americans, Orono. 
Levine, M., 1982. The use of crown height measurements and eruption-wear sequences to age horse teeth, p. 223-250. In B. Wilson, C. Grigson and S. Payne, eds., Ageing and Sexing Animal Bones. British Archaeological Reports 109, Oxford.

MacFadden, B.J., 1992. Fossil horses: Systematics, paleobiology and evolution of the family Equidae. Cambridge University Press.

Matthews J.V., 1982. East Beringia during the Late Wisconsin time: A review of the bioticevidence, p. 127-150. In D.M Hopkins et al., eds., Paleoecology of Beringia. Academic Press, New York.

Morlan, R., 1980. Taphonomy and archaeology in the Upper Pleistocene of the Northern Yukon Territory: A glimpse of the peopling of the New World. Archaeological Survey of Canada Mercury series 94, Canadian Museum of Civilization, Ottawa.

Prat F., 1968. Recherches sur les Équidés Pléistocènes en France. Thèse universitaire, Université de Bordeaux, 329 p.

1976. Les Périssodactyles: équidés, p. 409-415. In La Préhistoire française. Cahiers du C.N.R.S., Paris
1980. Les équidés Villafranchiens en France; Genre Equus. Éditions du C.N.R.S., Paris.

Quinn, J.H. 1957. Pleistocene Equidae of Texas. University of Texas Bureau of Economic Geology Reports, 33: 1-51.

Savage, D.E., 1951. Late Cenozoic Vertebrates of the San Francisco Bay Region. University of California Publications, Department of Geological Science Bulletin 28: 215-314.

Turnbull P., 1986. Measurements of Equus hemionus from Palegawra Cave (Zarzian, Iraq). In R.H. Meadow and H.-P. Uerpmann, eds., Equids in the Ancient World. Dr. Ludwig Reichart Verlag, Wiesbaden.

Vereshchagin, N.K. and Baryshnikov, G.F., 1982. Paleoecology of the mammoth fauna in the Eurasian Arctic, p. 267-280. In D.M Hopkins et al., eds., Paleoecology of Beringia. Academic Press, New York.

von den Driesch, A., 1976. A guide to the measurement of animal bones from archaeological sites. Peabody Museum Bulletin 1. Cambridge.

Waring, G.H. 1983. Horse Behavior. Noyes Publications, Park Ridge (New Jersey). 